\title{
FEMINISM AND CONVENTIONALITY
}

\author{
By Elsie Clews Parsons,
}

\author{
Newport, R. I.
}

A few years ago there was discussion in academic circles over differentiating the college curriculum of women from that of men. Surely the curriculum for men is not so satisfactory, it was urged, that it cannot be improved. Besides, the educational needs of women may be different, if only a little, from the needs of men. "True, perhaps," was the answer of the advocates of an identical curriculum, "but even so, we can't afford to differentiate, as yet at least. To give women as 'good' an education as men, we must give them the same education. That is the only way we can keep up the standard." And hitherto in the colleges this plea, right or wrong, has governed. It is the same argument that underlies feminist effort in other fields. That women may have as ample opportunities throughout society as men, they must have, it is felt, more or less consciously, the same opportunities. Society is after all very simple minded, one new idea at a time is its measure. Let not feminism confuse its issues. Before women can improve on men's ways, those ways, one and all, must be open to women.

Whether or not this is sound feminist doctrine, it is the clue to an understanding of much of the feminist agitation of today. It suggests, too, some of the directions still to be taken by the feminist movement. It may be profitable therefore to consider some of the differentiations ${ }^{1}$ in habits and customs that have arisen in society for the lives of men and women, the differentiations of daily life and of life at crises, not overlooking, where we can discern them, the psychological reasons for these differentiations.

"So long as a lady shall deem herself in need of some gentleman's arm to conduct her properly out of a dining or ballroom,"

1 Not all; feministic discussion must confine itself, for example, to the exclusiveness of men, trusting that the exclusiveness of women will some day be a matter for hominist agitation. The farseeing feminist trusts, too, that the legal rights of men will cease to be neglected-inequalities before the law in responsibility for crime, for example, and in matters of property (damages for breach of promise, alimony, or any legal obligation to support women). 
wrote an American publicist over half a century ago, "so long as she shall consider it dangerous or unbecoming to walk half a mile alone by night-I cannot see how the Woman's Rights' theory is ever to be anything more than a logically defensible abstraction." If this opinion of Horace Greeley is to be taken as a prediction that the Woman's Rights' platform of his time would not be enacted until another measure of freedom was secure to women, it has not been justified by the course of events. Property disqualifications have been entirely removed from women, the right of guardianship has become theirs (to the extent it was originally desired), and the days are counted to their possession, throughout the country, of the right of suffrage. These rights are theirs and yet it still embarrasses a woman to stand alone in a ballroom or sit with other women after the men have come out from the smoking-room; and it may be that the woman allured by the mystery of solitude under the stars is still rare. But perhaps what Greeley meant to say was that economic or political reform would not greatly affect women as long as the conventionalities of their daily life remained unchanged. If so, was he not, in the main, right and for his period extraordinarily discerning? Even today, many a suffragist, however ardent, is unpossessed of this insight. Anxious beyond measure for the vote, she is wholly unperturbed by the constraints of her daily life. Loath to be wholly dependent upon men in the limited number of matters which make up government, she is willing enough to bedependent upon them and upon women too in those endless details of daily life any woman might be expected to determine for herself. I recently attended a political convention at Saratoga where several women were lobbying for suffrage. One evening one of them wanted to go with a man to a dance, but she would not go, I overheard her declare, unless another woman went with them. The following afternoon another suffragist who had started to motor to New York took the train at Albany because, thanks to an unforeseen emergency, one of the two men motoring with her had to remain in Albany. "I couldn't think of getting into New York after midnight with only one man . . . ." Is not chaperonage a more important question for women, I wonder, than suffrage?

Comparative inability to choose either solitariness or their company is not characteristic merely of modern women. In no culture bave women shown desire to do anything which requires running 
the risks of being alone. Women hermits are extremely scarce, there are few women explorers, there are no women vagabonds, even the licensed adventuress, too restricted in her activity for any real adventure, is outcasted in a group. Rarely indeed do women go off by themselves-into the corner of a ballroom, into the wilderness, to the play, to the sacred high places of the earth or to the Islands of the Blessed. Penelope stays at home. Her reasons for staying at home vary, of course. She has to help her mother; she will be raped by a licentious male, a man or perhaps a god; she owes obedience to her parents; she will lose her reputation; she will give birth to a monster or her baby will die; she has to get the dinner ready; she has to look after the baby; she will bring disgrace to her family, dishonor to her husband, shame upon her children, disaster to her clan.

Whatever the sanctions, whatever the necessities or the excuses, woman's place having been in the home, her acquaintances have been restricted to the family circle and to the segments of the other family circles it overlaps. And with these friends and relatives her intercourse is unbroken and more or less incessant. The womanly woman has ever been an available woman, "always there when you wanted her." From such "home life" there have been for all women two prime outcomes. The unfamiliar person, the stranger, has been feared and shunned, more feared and shunned by women even than by men. Women in other words are peculiarly apprehensive of people of other localities, of other tribes or nations, of other castes, of other sets; and with such outlanders or outsiders they have as little to do as possible. Women are "inhospitable." They are "snobs." They are "full of prejudices." They are not "good mixers."

But to this characteristic tendency of women to keep to themselves, there are two exceptions. Within the home itself women associate with strangers, i.e., with those unlike themselves, unlike in age and in sex, and seldom, too, are the times when women do not have to put up with this association. Being "home bodies," they cannot get away, like men, from their children or their parents, they have to make the best of their brothers or their husbands. Face to face with these heterogeneities of sex or age, women have raised up barriers against them, carefully regulating their relations with their juniors and seniors and with the other sex. Their attitude 
is very conventional with members of different age classes and with men, more conventional, I mean, than that of men with women or with those unlike in age-and this is the second important outcome for women of their home life. Upon women age and sex taboos are heavier than upon men. And it is they who are the foremost teachers of the proprieties, of politeness, of good manners, of the amenities-all rules of conduct for life with others more or less unlike yourself and yet not to be avoided.

With beings unlike yourself the alternative to conventionality is avoidance. And that alternative is taken on the whole by men in relation both to their juniors and seniors ${ }^{2}$ and to women. More or less unconsciously they avoid women and more or less deliberately they exclude them from their interests and their places of assemblyfrom their economic pursuits, from their learned professions, from their games and pastimes, from their club-houses, churches, ${ }^{3}$ forums, council halls, universities, and play-houses. Even the initiative in the avoidance practiced within the family group is taken, I surmise, by men. ${ }^{4}$ At home and away from it such seclusiveness and exclusiveness in men result, of course, in increasing the differences between them and women. Increased differences stimulate to greater seclusiveness or exclusiveness; we get a closed circle.

2 Although classification by age is characteristic of every society, our specific data on age classes are scant and very scattered; but from what I have from others and have observed at first hand I am inclined to believe that seniority is more of a bar in daily intercourse between adult men than between women. The fact that men see comparatively little of children hardly needs mention. Seeing them seldom, they can afford, they feel, to treat them as contemporaries. This is a reason why children "take to men" and not, as a fond mother sometimes alleges, because men are novelties. Children, like women, dread the Stranger.

- From religious exclusiveness almost all other forms of exclusiveness can be traced just as all the professions were differentiated from the priesthood and as games and the arts had religious origins. But the exclusion of women from the derivatives of ecclesiasticism is no mere historical sequence or survival. History gives it the sanction of the past in given cases, but it has an ever fresh psychological spring.

4 Among us it is the son-in-law who avoids his mother-in-law and there appears to be no evidence that it is the other way round among savages where this practice is more formal. At any rate it is the father-in-law in every society who avoids his daughter-in-law and not vice versa. Everywhere, too, it is "up to" the boy to stop "hanging round" his mother and playing with his sisters. 
For the moment let us turn away from this closed circle to consider certain sex differentiations in customs at times of crisis. We noted that the heterogeneities of sex and of age are more constantly under the noses of women, so to speak, than of men. Women are closer to life, we sometimes say, meaning that they are face to face with birth and growth, decay and death. And so it is to be expected that they, rather than men, will play the leading parts in the policy human beings have chosen to meet the changes of lifethe policy of ignoring the change until it is inevitable and then mitigating the shock of it through the diversion of ceremonial. ${ }^{5}$ And women do play in the ceremonial of crisis the more prominent or lasting rôles. Mourning observances are far more elaborate for women than for men and far more prolonged. So are wedding and honeymoon observances, although in them of course the character of duality must preclude any great differentiation. ${ }^{6}$ As for puberty or initiation ceremonial, that curious means of breaking the shock of realizing that the young have grown up, if women appear to take a less important part in it than men, reasons consistent with our general interpretation are not hard to find. The initiation of boys means they are leaving home. No amount of ceremonial can disguise that break. Were they to stay on at home in a different relation to it, then the women might enter more strikingly into their man-making rites. ${ }^{7}$ As it is, all women can do is to express ceremonially their distress at "losing" their boys. Andamanese women "weep over" an initiate the morning after he breaks his turtle fast. Throughout the first night of an initiation Mita-Koodi women are expected to wail. The kinswomen of an Euahlayi initiate are supposed to be so much in need of comforting that the old men bring them presents of food. In other Australian tribes we find rites to symbolize the separation imminent between the initiate and his kinswomen. Among the Kurnai he sprinkles his mother with water, among the Arunta he throws his boomerang towards her spirit camp to show her, the

- Under the rubric of Ceremonial Reluctance I am preparing a fuller statement of this shock absorber theory of ceremonial.

- The veiling of the bride and her seclusiveness before and after the wedding are the most notable. But the bridal couple apart, the women of the family are more concerned with the marriage ceremonial than the men.

"As they do at the nubility of girls; for the "coming out" rites of girls do not mean a break with family life. 
ethnographers suggest, that all is at an end between them. ${ }^{8}$ But the initiates are turning their backs on their mother only to turn their faces towards their father and their father's friends. For these seniors, upon taking into their life youthful participants, an adjustment is necessary, and it is for them to get it over with as quickly and easily as possible. Naturally they resort to the usual social method, the method of ceremonial. It is plain enough why men figure rather than women in the puberty or initiation rites to celebrate a boy's growing up.

But there are other conditions in the life of men besides an adjustment to their juniors to be met with ceremonial or with conventionality. Their contacts with all their non-familial groups, the groups they resort to when they leave home, when they go out "to meet a man," all these associations have to be entered upon with ceremonial and, their membership never entirely homogeneous, safeguarded with conventionalities. Hence presentations and introductions of all kinds, the conferring of orders or degrees, the induction into office, "treating" and the "sacred laws of hospitality." Hence tribal or patriotic standards, professional etiquette, chivalry, the code of a gentleman, and many other caste taboos or rules. In all these matters women figure far less than men, of course, for the simple enough reason that they are out of touch with the different groups concerned. They have avoided them or they have been excluded from them. Then when they do begin to seek admission into these non-familial groups we may note that very often they ride roughshod over their conventionalities, ${ }^{9}$ breaking their rules, either because they are ignorant of them or because they see in them little or no value. This procedure, whatever its explanation, is very disturbing to men, distasteful to them and even abhorrent. And often enough it is the more or less unconscious anticipation of such violations by women, of such misbehaviour, that sets men so bitterly against opening the doors to them. Merely to lessen masculine apprehensiveness and to overcome masculine antagonism women might do

${ }^{8}$ The rigid separation of initiates from females is also more of a symbol of sex segregation, I think, than a practical measure against sexual intercourse. It is a concentration rite, a synopsis, so to speak, of the life ahead of them, life apart from women.

- An infraction we recognize when we say, for example, that women have no sense of honor, or that women dislike "red tape." 
well to adopt quickly and unquestioningly masculine conventionalities.

But even if women develop a sense of honor and a respect for masculine routine, even if they shear their hair and dress like men, even if they keep men's hours, and work and play like men, even if they smoke and swear and get drunk like men, even if they succeed in getting from the outside the loyalty and esprit du corps that usually come only with participation in the life of the group, learning to swim, in other words, without going near the water, even if they conform in all these ways, differences will still exist between them and men, natural differences, urges the anti-feminist, and should not these natural differences receive appreciation and be given social expression? However we may answer this question, it does not quite meet the point of masculine exclusiveness. It is apprehension of difference rather than actual difference which bulks so large now and always in the social regulation of sex. It is fear of the unlike rather than the fact of it. The anti-feminist wishes to keep women apart from men not because he values sex differences, but because he fears them. He or she is not so anxious to preserve them as to get away from them, to be protected from the danger of being disturbed by them. Differences in age, in caste, in family, and in race, have filled mankind with analogous apprehensions and prompted analogous methods and plans of self-protection.

Age-class, caste group, family, and race, each has its own closed circle-from unlikeness to exclusion or seclusion, from exclusion or seclusion to unlikeness-but each of these vicious circles the modern spirit has begun to invade and break down. In the spirit of our time fear of the unlike is waning, and pari passu intolerance. Fear of the unlike and intolerance are due to fear of change, and that fear, whether of change wrought by life or of change threatened by the stranger, that great fear, is passing. With it are bound to go the devices of self-protection it prompted-ceremonial, conventionality, and segregation. In this general movement of the human spirit feminism was born; upon its march the hopes of feminism ultimately must depend. 